\title{
FOCUS GROUP TO CREATE A VIRTUAL CASE STUDY MODEL UNIT FOR THE DMU E-PARASITOLOGY
}

\author{
A. Peña-Fernández ${ }^{1}$, A. Magnet ${ }^{2}$, M.A. Peña ${ }^{3}$ \\ ${ }^{1}$ De Montfort University, Faculty of Health and Life Sciences (UNITED KINGDOM) \\ ${ }^{2}$ Universidad San Pablo CEU, Facultad de Farmacia (SPAIN) \\ ${ }^{3}$ Universidad de Alcalá, Departamento de Ciencias Biomédicas (SPAIN)
}

\begin{abstract}
De Montfort University (DMU, Leicester, UK) is leading a teaching innovation project for the creation of a complete package for teaching and learning human parasitology in collaboration with the Spanish universities: San Pablo CEU and Miguel Hernández, and practicing Biomedical Scientists from the UK National Health Service. The DMU e-Parasitology package will be freely available on the DMU website (http://parasitology.dmu.ac.uk/) late in 2018 and present three modules: a theoretical unit for the study of medical parasitic diseases; a virtual laboratory and microscope sections with a complete collection of clinical slides for the study of these major diseases. To provide the user of this novel package with a holistic and complete experience for the learning of medical parasitology we have started the development of a fourth section, which will hold highly interactive virtual case studies in which the user will be provided with a medical history and different clinical slides to identify the parasites and their structures. The user will need to reflect and critically think to suggest potential diagnoses, additional diagnostic techniques, treatment and prevention techniques for that parasitic disease. A first virtual case study has been created in the DMU e-Parasitology here: http://parasitology.dmu.ac.uk/learn/ case_studies/cs1/story_html5.html, as described in Peña-Fernández et al. (2018) [1]. The degree of difficulty is medium-high, so a background in parasitology is needed to resolve it. Comprehensive student feedback is being collected to improve this case study, which will be used as a model unit to develop future case studies for this section. To determine the feasibility of this case study to train postgraduate students, DMU students attending the MSc Advanced Biomedical Science have completed the case study during a workshop session specially delivered this academic course $2017 / 18(n=9)$. We collected the following results: $100 \%$ students indicated that the eParasitology is interactive $(71.4 \%$ agreed, 28.57 strongly agreed), and the case-study presented was appropriate for their studies (57.1\% agreed, $42.9 \%$ strongly agreed). In relation to the content, all students highlighted that it was relevant for their studies $(42.9 \%$ agreed, $57.1 \%$ strongly agreed), and indicated that the exercises presented were easy to understand $(71.43 \%$ agreed, $28.57 \%$ strongly agreed). In the freeopen questions available in the questionnaire, postgraduate students demanded more case studies and mini-formative assessments within the theoretical units that they reviewed to answer the virtual case study (free-living amoebas and Entamoeba histolytica). Finally, they suggested the provision of the correct answers throughout the case study instead of at the end.
\end{abstract}

Keywords: DMU-eParasitology, medical parasitology training, reflection, critical thinking, virtual case studies.

\section{INTRODUCTION}

Increasing numbers of food-, water- or vector-borne parasitic disease outbreaks are being described in developed countries, highlighting the relevance of teaching medical parasitology. Moreover, the globalisation phenomenon is bringing new threats including an increase in imported parasitic diseases, for example Taenia solium [2]. Despite this, the latest study indicating the current status of teaching of parasitology in different European countries was reported by Bruschi (2009) [3]. Different studies have documented a decrease of parasitology departments and the time dedicated to the study of this discipline in developed countries [3-5].

As a consequence, our teaching innovation group is developing a complete on-line package for teaching and learning parasitology in collaboration with different European Universities including De Montfort University (DMU, Leicester, UK) and the Spanish Universities of San Pablo CEU (Madrid) and Miguel Hernández de Elche (Alicante), in conjunction with clinicians and practising biomedical scientists from the UK National Health Service. This package has been named DMU e-Parasitology and it will be publicly available on the DMU website, here http://parasitology.dmu.ac.uk/, in 2018. 
A description of the structure of this novel package has been provided in Peña-Fernández et al. (2017) [6] and in a presentation available in the UK Advanced Higher Education's (formerly Higher Education Academy) Knowledge Hub [7], and is briefly detailed below. The package has four major modules or sections as follows:

1 A theoretical module with e-learning units to study major human parasites including protozoa, fungi, helminths and arthropods.

2 A virtual laboratory module with different units about techniques and equipment for the study of parasitic human diseases. More information will be available in Peña-Fernández et al. (2018) [8].

3 A virtual microscope with a real slide collection of clinical slides of human parasites, which has been described previously [9].

4 A module with virtual clinical case studies (Figure 1), which is being built here, http://parasitology.dmu.ac.uk/learn/case-studies.htm. A brief description is provided below.

\subsection{Virtual clinical case study model}

The first virtual clinical case study created involves an HIV positive young male adult infected by the parasites of Entamoeba histolytica and Acanthamoeba spp. and is available here: http://parasitology.dmu.ac.uk/learn/case_studies/cs1/story_html5.html [10]. The virtual case study was developed using the Articulate 360 software. The case study presents a series of clinical slides on the above emerging human pathogens parasites in conjunction with a brief medical history and a combination of tests/quizzes and exercises (Figure 2) with different degrees of difficulty so the user is challenged throughout its completion (Figure 1). The user will use the virtual microscope to morphologically identify the parasite(s) involved. A description of this first virtual case study can be found in Peña-Fernández et al., (2018) [1].

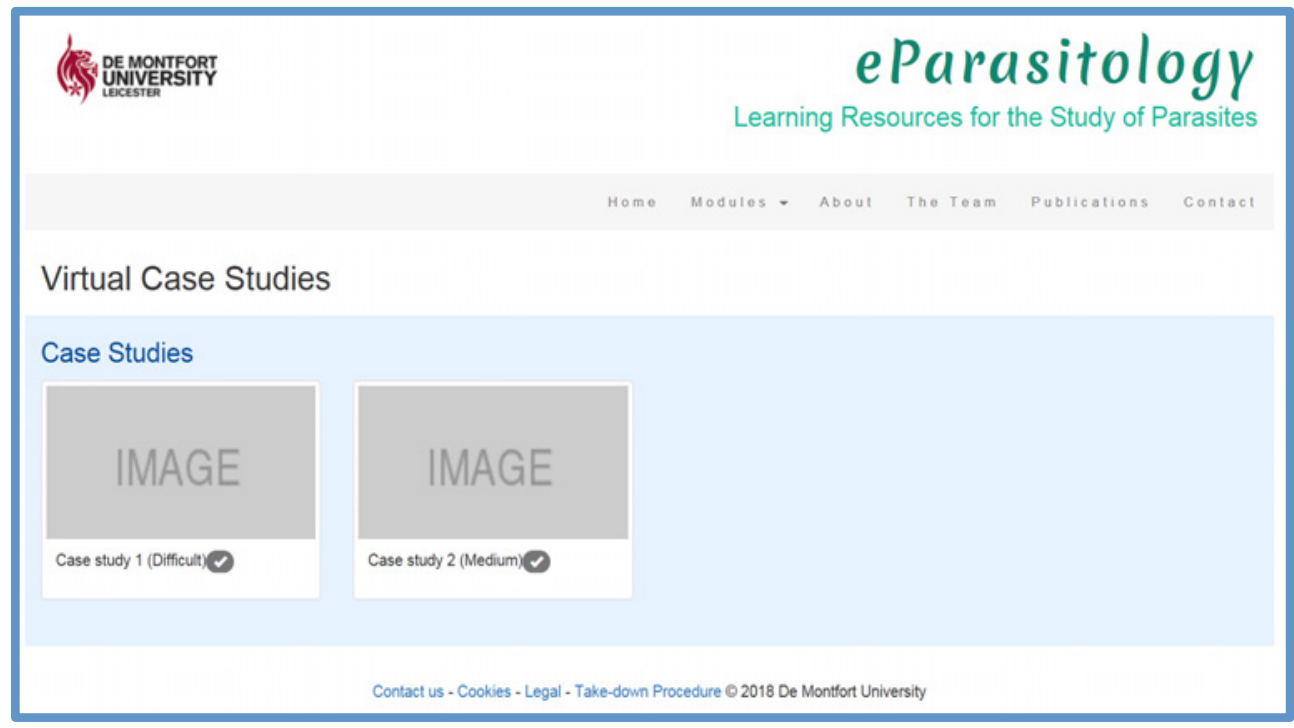

Figure 2. Overview of DMU e-Parasitology's virtual case studies module (Image courtesy of DMU). Available at: http://parasitology.dmu.ac.uk/learn/case-studies.htm 


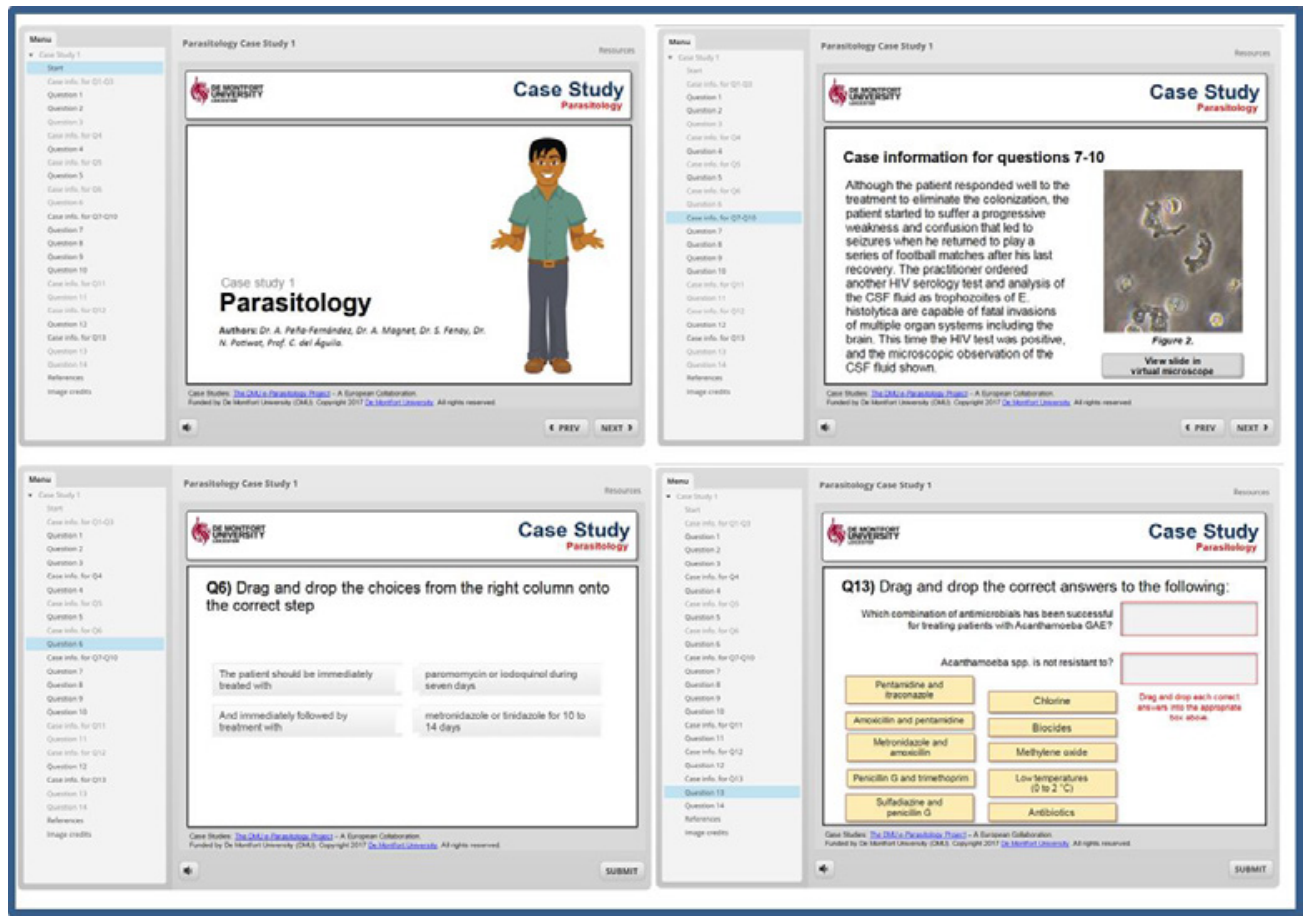

Figure 1. Overview of the first virtual case study for DMU e-Parasitology in which the applicability of the virtual microscope is shown (Image courtesy of DMU; Peña-Fernández et al., 2017 [10]). Available at: http://parasitology.dmu.ac.uk/learn/case_studies/cs1/story_htm/5.html

The main aim of this paper is to determine the effectiveness of this case study to enhance the learning experience of the user and whether it can facilitate the learning of medical parasitology. This unit will be improved following student feedback and experience and used as a model unit to develop this key module of the future DMU e-Parasitology.

\section{METHODOLOGY}

To meet these objectives, we have performed qualitative and quantitative analysis after delivering a highly specific workshop to a focus group of MSc students enrolled in the programme of Advanced Biomedical Science at DMU in 2017/18. To complete the workshop, students, working in pairs in a computer-lab room, needed to explore other modules within DMU e-Parasitology and use specific tools such as the virtual library and the microscope. Therefore, students gained an overview of DMU e-Parasitology, which would then facilitate their evaluation of the virtual case study, how it fits within this novel learning package and how we could enhance/improve it. Feedback was collected by the end of the workshop using a specific feedback-questionnaire with a mix of Likert style and open questions, following previous successful experiences by our team. Ethical approval was granted by the Research Ethics Committee at DMU (Ref. 1851; 8th December 2016).

\section{RESULTS AND DISCUSSION}

The MSc students showed significant interest in this topic, indicated by the extensive discussions generated during the 1 hour workshop. Overall, the workshop was positively received by the students, revealed by the favourable responses from the class with all participants indicating high levels of enjoyment (50\% agreed, $50 \%$ strongly agreed) and satisfaction $(83.3 \%$ agreed, $16.7 \%$ strongly agreed). Moreover, they considered that the knowledge learnt will help them in their future career $(100 \%$ agreed).

With respect to DMU e-Parasitology overall, participants indicated that the novel package is interactive (71.4\% agreed, 28.57 strongly agreed), appropriately designed $(57.1 \%$ agreed, $42.9 \%$ strongly agreed) and the design of the virtual laboratory (100\% agreed) and microscope (71.4\% agreed, $28.6 \%$ strongly agreed) were suitable. 
In relation to the virtual case study, all students highlighted that it was relevant for their studies $(57.1 \%$ agreed, $42.9 \%$ strongly agreed), and helped them to gain knowledge on the pathology, prevention and treatment of the human parasitic diseases considered in the case study (57.1\% agreed, $42.9 \%$ strongly agreed).

\section{CONCLUSIONS}

Following the feedback provided by this focus group, only minor improvements were performed to publish the first virtual clinical case study, which were mostly related with changes in the writing for enhancing clarification or understanding for the student/user. This virtual case study is currently being used as a model to build this module or section of the future DMU e-Parasitology, which will present different cases with variable degree of difficulty, to facilitate the use of this package in any undergraduate and/or postgraduate human health programme.

\section{ACKNOWLEDGEMENTS}

The authors would like to express their sincere appreciation to Jonathan Coope and Maxine Armstrong (DMU) for work on development of DMU e-Parasitology and to USP-CEU Parasitology laboratory for providing high-quality images of parasites in different clinical and culture samples. Finally, we would like to thank the Teaching Innovation Project Fund at De Montfort University (scheme 2015-16) to fund this project to Dr. Peña-Fernández.

\section{REFERENCES}

[1] Peña-Fernández A., Peña MA., Potiwat N., Coope J., Magnet A. Virtual case studies in the novel resource DMU e-Parasitology. INTED2018 Proceedings; 6201-6206. ISBN 978-84-6979480-7.

[2] Gómez-Morales MA., Gárate T., Blocher J., Devleesschauwer B., Smit GSA., Schmidt V., Perteguer MJ., Ludovisi A., Pozio E., Dorny P., Gabriël S., Winkler AS. Present status of laboratory diagnosis of human taeniosis/cysticercosis in Europe. Eur J Clin Microbiol Infect Dis. 2017; 36(11):2029-2040.

[3] Bruschi F. How parasitology is taught in medical faculties in Europe? Parasitology, lost? Parasitol Res 2009; 105(6):1759-62.

[4] Peng HJ, Zhang C, Wang CM, Chen XG. Current status and challenge of Human Parasitology teaching in China. Pathog Glob Health 2012; 106(7):386-90.

[5] Acholonu AD. Trends in teaching parasitology: the American situation. Trends Parasitol 2003; 19:6-9.

[6] Peña-Fernández A., Ollero MD., Fenoy S., Magnet A., Izquierdo F., Peña MÁ., Bornay F., Acosta L., Parker LA., Sgamma T., Del Águila C. Creating a model module for the novel resource DMU e-Parasitology. ICERI2017 Proceedings; 1599-1604. ISBN: 978-84-697-6957-7.

[7] Peña-Fernández A., Magnet A., Acosta L., Evans MD., Fenoy MS. Developing a digital environment for teaching and learning parasitology. Higher Education Academy STEM conference 2018, Newcastle, UK, 31st Jan - 1st Feb 2018. Oral presentation. Available at: https://www.heacademy.ac.uk/knowledge-hub/developing-digital-environment-teaching-andlearning-parasitology-stem-conference

[8] Peña-Fernández A., Fenoy S., Evans MD., Sgamma T., Hurtado C., Izquierdo F., Randles M., Young C., Acosta L., del Aguila C. Development of a virtual environment for teaching and learning biomedical techniques and equipment for the study of human pathogens. EduLearn2018 Proceedings; submitted for publication.

[9] Peña-Fernández A., Fenoy S., Halliwell R., Izquierdo F., Magnet A., Hurtado C., Bornay F., Acosta L., Ollero MD., Armstrong M., Evans MD., Del Águila C. Development of a virtual library of clinical samples for medical parasitology diagnosis. INTED2018 Proceedings; 7599-7604. ISBN 978-84-697-9480-7. 
[10] Peña-Fernández A, Magnet A., Fenoy S, M.A. Peña, Potiwat N, del Águila C. Case study 1 DMU e-Parasitology. Available at:

http://parasitology.dmu.ac.uk/learn/case_studies/cs1/story_html5.html [Accessed 10/05/2018] 